\title{
Two retarded male cousins with odd facies, hypotonia, and severe constipation: possible examples of the $\mathrm{X}$ linked FG syndrome
}

\author{
J BURN* AND N MARTIN $\dagger$
}

From *the MRC Clinical Genetics Unit, Institute of Child Health, 30 Guilford Street, London WC1N 1EH; and †the Children's Department, London Hospital (Whitechapel), Turner Street, London E1 1BB.

SUMMARY A boy was referred in 1977 for investigation of global retardation and hypotonia. Minor dysmorphic features and intractable constipation were noted. In 1981 the mother's sister had a son with a similar phenotype. This is probably the X linked Opitz-Kaveggia or FG syndrome.

In 1974 Opitz and Kaveggia ${ }^{1}$ reported a kindred in which five males in two sibships had a similar syndrome of hypotonia, unusual facies, retardation, and in four of the five, imperforate anus. They suggested the condition be called the FG syndrome after the family initials. We present two males who, probably as a result of an $\mathrm{X}$ linked recessive gene defect, had a syndrome whose facial and neurological features closely resembled the FG syndrome. Neither had imperforate anus but both developed severe and intractable constipation within weeks of birth. We discuss the diagnostic definition of the FG syndrome in the light of these observations.

\section{Case reports}

Fig 1 shows the pedigree. II.4 and II.5 died in infancy. III.8 and III.9 each died at 18 months of age. All four were known in the family as 'sickly Received for publication 23 July 1982. babies '. No further information is available. Fig 2 shows the facial appearance of the two cousins and the table lists their clinical features. Both were born preterm with weights in the lower normal range, but subsequently showed marked failure to thrive. Both were floppy from birth, the hypotonia persisting until the death at 23 months of V.1. V.2 was examined at 7 months and was markedly hypotonic at that stage. Fig 2 (lower two photographs) shows the only record of the facial appearance of V.1. It can be seen that he had a tall broad forehead, epicanthic folds, and abnormal folding of the left helix. After the birth of V.2, the mother of V.1 was struck by the similarity in the facial appearance of the two boys. Again, a tall forehead, with epicanthic folds and minor anomalies of helix formation were evident. In particular, there was prominence of the antihelix. V.2 had large corneae. Both boys had a drooping expressionless face with an 'inverted $\mathrm{V}$ ' upper lip. V.2 had a capillary haemangioma on the

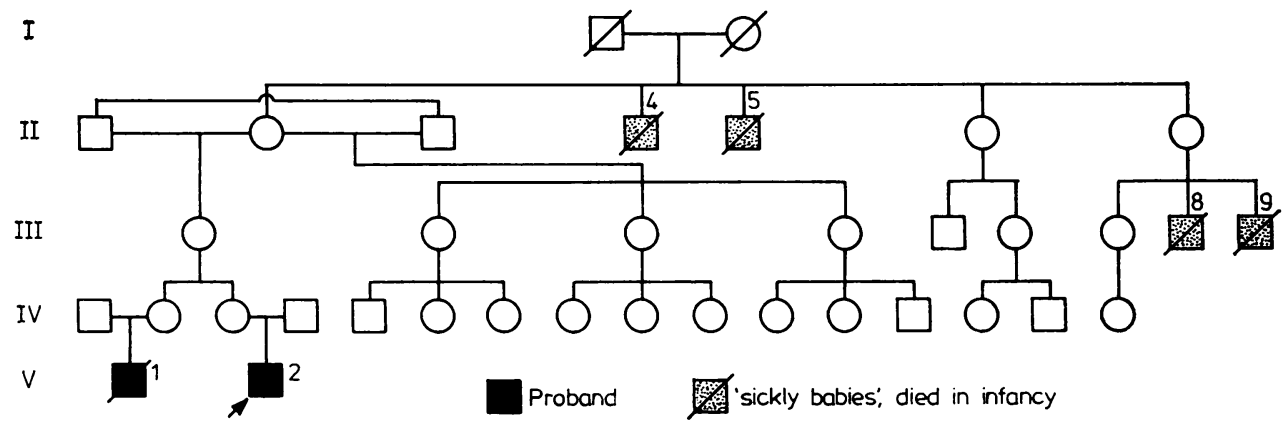

FIG 1 Pedigree. 


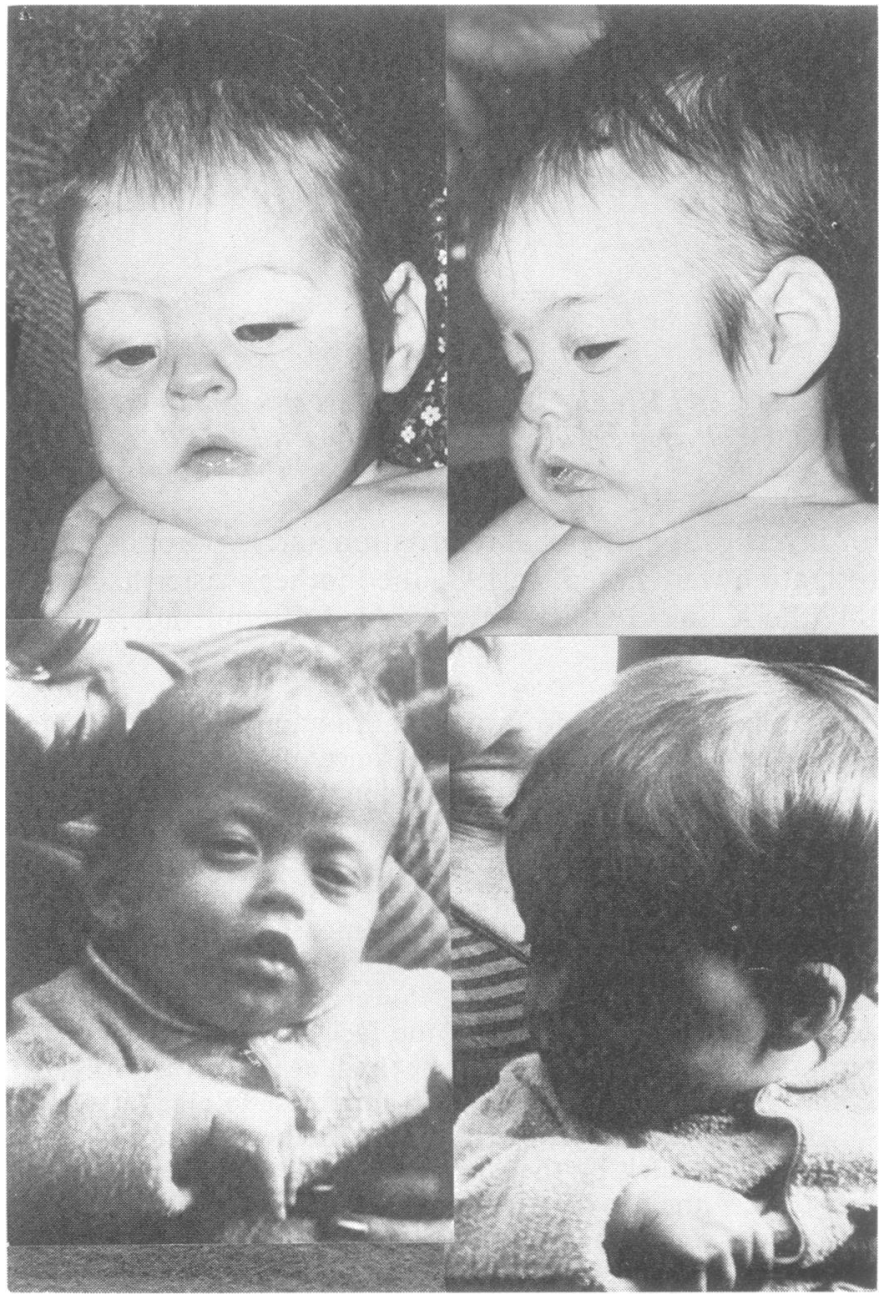

FIG 2 Facial appearance of the two cousins. V.1 is shown in the lower photographs.

left frontal parietal region and a single palmar crease on the left hand. When measured at 23 months, V.1 had a weight 4.1 SD below the mean and the head circumference was $2.4 \mathrm{SD}$ below the mean. At 7 months V.2 had a weight 3.8 SD below the mean and a head circumference of 3.4 SD below the mean.

A striking clinical feature in both infants was severe and intractable constipation. In V.1, this became evident shortly after birth and was resistant to continual laxative therapy. Hirschsprung's disease was suspected but rectal biopsy revealed normal innervation and barium enema showed general dilation of the sigmoid without any clear line of demarcation. In V.2, constipation became evident in the third week of life and the child required repeated courses of powerful laxatives thereafter. Studies of thyroid function revealed no abnormality.
Chromosome analysis in V.1 revealed a shortening of the long arm of chromosome 16 . The same change was evident in the mother's karyotype and this was interpreted as being a familial polymorphism not relevant to the child's dysmorphic syndrome. Detailed chromosome analysis was performed on V.2 and this was reported to be normal by the local Regional Cytogenetics Unit, in the knowledge of the polymorphism present in the other child.

\section{Discussion}

It is evident from the close similarity shown in the table that these two boys suffered from the same syndrome. In the absence of demonstrable chromosome abnormality, the pedigree points strongly towards an $\mathrm{X}$ linked recessive disorder with 
TABLE Comparison of clinical features in the two affected cousins.

\begin{tabular}{|c|c|c|}
\hline & $V .1$ & $V .2$ \\
\hline Gestation & 33 weeks & 35 weeks \\
\hline Birth weight & $1.9 \mathrm{~kg}$ & $2 \cdot 1 \mathrm{~kg}$ \\
\hline Face & $\begin{array}{l}\text { Bossed forehead, } \\
\text { epicanthic folds, } \\
\text { lack of expression }\end{array}$ & $\begin{array}{l}\text { Bossed forehead, } \\
\text { epicanthic folds, } \\
\text { lack of expression, } \\
\text { large corneae }\end{array}$ \\
\hline Ears & $\begin{array}{l}\text { Prominent left } \\
\text { antihelix }\end{array}$ & $\begin{array}{l}\text { Bilateral prominent } \\
\text { antihelix }\end{array}$ \\
\hline Weight & $\begin{array}{l}7 \cdot 75 \mathrm{~kg} \\
(-4 \cdot 1 \mathrm{SD} \text { at } \\
22 \mathrm{mth})\end{array}$ & $\begin{array}{l}4 \cdot 8 \mathrm{~kg} \\
(-3 \cdot 8 \mathrm{SD} \text { at } \\
7 \mathrm{mth})\end{array}$ \\
\hline $\begin{array}{l}\text { Head } \\
\quad \text { circumference }\end{array}$ & $\begin{array}{l}45 \cdot 5 \mathrm{~cm} \\
(-2 \cdot 4 \mathrm{SD} \text { at } \\
22 \mathrm{mth})\end{array}$ & $\begin{array}{l}39 \mathrm{~cm} \\
(-3.4 \mathrm{SD} \text { at } \\
7 \mathrm{mth})\end{array}$ \\
\hline Brain & $\begin{array}{l}\text { CAT scan cerebral } \\
\text { atrophy, post } \\
\text { mortem brain } 971 \mathrm{~g} \\
(10 \% \text { below } \\
\text { normal), excess CSF } \\
\text { over hemispheres }\end{array}$ & No information \\
\hline Nervous system & $\begin{array}{l}\text { Persistent hypotonia, } \\
\text { marked develop- } \\
\text { mental delay, } \\
\text { frequent vomiting, } \\
\text { poor suck, } \\
\text { tendency to arch } \\
\text { back }\end{array}$ & $\begin{array}{l}\text { Persistent hypotonia, } \\
\text { marked develop- } \\
\text { mental delay, } \\
\text { choked on feeds, } \\
\text { poor suck, } \\
\text { tendency to arch } \\
\text { back }\end{array}$ \\
\hline Large intestine & $\begin{array}{l}\text { Severe constipation } \\
\text { resistant to } \\
\text { laxatives, barium } \\
\text { enema-functional } \\
\text { megacolon, lax } \\
\text { anal sphincter }\end{array}$ & $\begin{array}{l}\text { Severe constipation } \\
\text { requiring laxatives }\end{array}$ \\
\hline
\end{tabular}

both mothers being carriers for this condition. Total absence of dysmorphic features in either mother or other members of the family make non-penetrance of a dominant disorder highly unlikely.

The clinical features described closely resemble those reported by Opitz and Kaveggia ${ }^{1}$ under the heading FG syndrome. Features in common are the postnatal growth failure, severe hypotonia, general developmental delay, relatively large head with frontal bossing, an expressionless face with inverted $\mathrm{V}$ of the lip, prominent epicanthic folds, and severe constipation. The original family contained five affected males in two sibships, four of whom had a membraneous imperforate anus. Keller et $a l^{2}$ reported a large kindred in which six males suffered mental deficiency and other features similar to those seen in the FG syndrome. Among the three survivors, only one had an abnormal anus. More recently Riccardi et $a l^{3}$ reported a third family and a further affected member of the original family. They supported the suggestion that this was a distinct syndrome and suggested that the distinction between the clinical reports of the first two families had related largely to the different age groups of the children observed. Of the 17 cases which have now been published ${ }^{45}$ five did not have anal atresia. Of the four with affected sibs to confirm the diagnosis, three survived. Two of these had severe constipation.
Of those who survived operation for anal atresia, five had persistent constipation or rectal anomalies or both.

In order to have a clear working definition of this syndrome, it has been the practice of many to regard imperforate anus as an essential diagnostic feature. In the isolated case this is not unreasonable since the other features in these children are rather subjective and remain, as yet, ill-defined. However, this approach is likely to underdiagnose the syndrome since one-quarter of the reported cases did not have an imperforate anus. Constipation is, of course, a frequent accompaniment of hypotonia and mental retardation. The onset in the early weeks of life noted in this report, however, despite the fact that both children were breast fed, suggests that this was a significant observation. The admission of V.1 for intensive investigation of bowel function, and the resistance of both to laxative therapy, serve to emphasise further the qualitative difference between the constipation seen in these boys and that seen commonly in retarded children.

The general agreement of the rest of the clinical picture together with the family pedigree leads us to the conclusion that these boys had the FG syndrome. This diagnosis should be considered in hypotonic retarded males in whom severe constipation is present from the early weeks of life.

We are grateful to Professor $\mathrm{O} \mathbf{H}$ Wolff and $\mathrm{Dr}$ N Royston for giving permission to report this family, and to Professor C O Carter for his encouragement and advice.

\section{References}

1 Opitz JM, Kaveggia EG. Studies of malformation syndromes of man. XXXIII. The FG syndrome. An $\mathrm{X}$-linked recessive syndrome of multiple congenital anomalies and mental retardation. $Z$ Kinderheilkd 1974;117:1-18.

2 Keller MA, Jones KL, Nyhan WL, Francke U, Dixson B. A new syndrome of mental deficiency with craniofacial, limb and anal abnormalities. J Pediatr 1976;88:589-91.

3 Riccardi VM, Hassler E, Lubinsky MS. The FG syndrome: further characterization, report of a third family, and of a sporadic case. Am J Med Genet 1977;1: 47-58.

4 Opitz JM, Kaveggia EG. FG syndrome. In: Bergsma D, ed. Birth defects compendium. New York: Alan R Liss, 1979.

5 Opitz JM, Kaveggia EG, Adkins WN, et al. Studies of malformation syndromes of humans. XXXIIIC. The FG syndrome-further studies on three affected individuals from the FG family. Am J Med Genet 1982;12:147-54.

Requests for reprints to Dr J Burn, MRC Clinical Genetics Unit, Institute of Child Health, 30 Guilford Street, London WC1N 1EH. 